\title{
Microbial regulation of nitrogen dynamics along the hillslope of a natural forest
}

\section{Kazuo Isobe ${ }^{1 *}$, Nobuhito Ohte ${ }^{1}$, Tomoki Oda ${ }^{1}$, Sho Murabayashi ${ }^{1}$, Wei Wei ${ }^{1}, K^{2}$,ishi Senoo ${ }^{1}$, Naoko Tokuchi ${ }^{2}$ and Ryunosuke Tateno ${ }^{2}$}

1 Graduate School of Agricultural and Life Sciences, The University of Tokyo, Tokyo, Japan

2 Field Science Education and Research Center, Kyoto University, Kyoto, Japan

\section{Edited by:}

Wilfred Otten, Abertay University, UK

\section{Reviewed by:}

Peter S. Hooda, Kingston University London, UK

Miguel Ángel Sánchez-Monedero, Spanish National Research Council, Spain

\section{*Correspondence:}

Kazuo Isobe, Department of Applied

Biological Chemistry, Graduate

School of Agricultural and Life

Sciences, The University of Tokyo,

1-1-1 Yayoi, Bunkyo-ku, Tokyo

113-8657, Japan

e-mail:akisobe@

mail.ecc.u-tokyo.ac.jp
Topography affects the soil physicochemistry, soil $\mathrm{N}$ dynamics, and plant distribution and growth in forests. In Japan, many forests are found in mountainous areas and these traits are often highly variable along steep slopes. In this study, we investigated how the microbial population dynamics reflected the bioavailable $\mathrm{N}$ dynamics with the physicochemical gradient along the slope in soils of a natural forest in Japan. We measured the gross rates of $\mathrm{NH}_{4}^{+}$production, nitrification, and $\mathrm{NH}_{4}^{+} / \mathrm{NO}_{3}^{-}$immobilization using the $\mathrm{N}$ isotope dilution method to analyze the $\mathrm{N}$ dynamics in the soils. We also determined the abundance of the bacterial 16S rRNA gene and bacterial and archaeal ammonia monooxygenase gene (amoA) using qPCR to assess the populations of total bacteria and nitrifiers. We found that gross rates of $\mathrm{NH}_{4}^{+}$production and nitrification were higher in the lower part of the slope, they were positively correlated with the abundance of the bacterial 16S rRNA gene and archaeal $a m o A$, respectively; and the availability of $N$, particularly $\mathrm{NO}_{3}^{-}$, for plants was higher in the lower part of the slope because of the higher microbial nitrification activity and low microbial $\mathrm{NO}_{3}^{-}$immobilization activity. In addition, path analysis indicated that gross rates of $\mathrm{NH}_{4}^{+}$production and nitrification were regulated mainly by the substrate (dissolved organic $\mathrm{N}$ and $\mathrm{NH}_{4}^{+}$) concentrations and population sizes of total bacteria and nitrifiers, respectively, and their population sizes were strongly affected by the soil physicochemistry such as $\mathrm{pH}$ and water content. Our results suggested that the soil physicochemical gradient along the slope caused the spatial gradient of gross rates of $\mathrm{NH}_{4}^{+}$production and nitrification by altering the communities of ammonifiers and nitrifiers in the forest slope, which also affected plant distribution and growth via the supply of bioavailable $\mathrm{N}$ to plants.

Keywords: ammonia-oxidizing archaea, ammonification, hillslope, nitrification, nitrogen dynamics

\section{INTRODUCTION}

In forests, the topography affects the soil environment such as the soil depth, soil formation processes, moisture content, and nutrient status, as well as the local climate (Hook and Burke, 2000; Tromp-van Meerveld and McDonnell, 2006; Penna et al., 2009). It may enhance the plant diversity in a forest, because spatial heterogeneity of environmental conditions allows plants with various physiologies to coexist. In Japan, many forests are found in mountainous areas; thus, the soil environments and plant diversity are highly variable along a steep slope (Enoki, 2003; Tateno and Takeda, 2003; Koyama et al., 2013). In general, a hydrological gradient is observed along a slope, from dry soil at the top part to wet soil at the bottom part. The soil chemistry such as $\mathrm{pH}$ and nutrient availability as well as the light intensity also exhibit gradients from the upper to lower parts. These gradients could affect the transient vegetation dynamics directly or indirectly (i.e., growth and distribution). The spatial differentiation of plants (e.g., plants adapted only to upper or lower slope conditions, or ubiquitously distributed plants) has often been observed and has been explained according to the availabilities of water, nutrients, or light for plants (Hook and Burke, 2000; Trompvan Meerveld and McDonnell, 2006; Engelbrecht et al., 2007). Nitrogen is considered to be a limiting nutrient for plant growth in most temperate forests (Vitousek and Howarth, 1991). The N availability for plants can be strongly affected by the hydrological factors on a slope (Hill and Kemp, 1999; Band et al., 2001). Therefore, many studies have focused on the patterns of soil $\mathrm{N}$ dynamics and $\mathrm{NO}_{3}^{-}$production as well as their controlling factors in forest slopes (Hirobe et al., 1998, 2003; Tokuchi et al., 2000; Nishina et al., 2009a,b; Koyama et al., 2013).

Microorganisms are responsible for the production of $\mathrm{NH}_{4}^{+}$ and $\mathrm{NO}_{3}^{-}$, which are the main forms of bioavailable $\mathrm{N}$ to plants, via the degradation of organic $\mathrm{N}$ and nitrification, respectively (Isobe et al., 2011a; Isobe and Ohte, 2014). Given that microbial activity levels reflect the dynamics of the bioavailable $\mathrm{N}$ in soil, we can expect that microorganisms will also have direct or indirect associations with the growth and distribution of plants via the supply of bioavailable $\mathrm{N}$ to plants. This association can also be found in the competition for $\mathrm{N}$ between microorganisms and plants. This competition can be harder for plants 
in N-limiting environments, because microorganisms generally have a higher affinity for bioavailable $\mathrm{N}$ than plants (Kuzyakov and $\mathrm{Xu}, 2013$ ). Microbial communities and their activities can be influenced by environmental conditions. Therefore, an environmental gradient may cause changes in the bioavailable $\mathrm{N}$ supply for plants via alterations in the microbial activity levels. In particular, many recent studies have shown that the rates of dissimilatory $\mathrm{N}$ transformation, such as nitrification and denitrification, could be explained by the sizes of nitrifier or denitrifier populations (Hawkes et al., 2005; Philippot et al., 2009; Isobe et al., 2012). Therefore, although few previous studies on forest slopes have focused on microbial population dynamics, we can expect that soil environmental gradients affect the transient vegetation dynamics on forest slopes by altering the population size of microorganisms responsible for the supply of bioavailable $\mathrm{N}$ to plants. With this, we can obtain a more mechanistic understanding of how soil environmental gradients affect the dynamics of bioavailable $\mathrm{N}$ and the plant diversity on forest slopes by considering microbial population dynamics and their associated activities.

The research site in the present study, Ashiu Forest Research Station, is a broadleaved deciduous forest located in Kyoto, Japan. Previous studies have found the gradient of soil physicochemistry and transient vegetation dynamics on a hill slope in this forest (Tateno and Takeda, 2003, 2010; Tateno et al., 2004, 2005). These studies showed that the soil properties, i.e., the water content, $\mathrm{pH}$, and $\mathrm{N}$ content, increased from the upper part to the lower part of the slope. The dominant plant species also differed between the upper and lower parts of the slope. Fagus crenata, a dominant and ubiquitously distributed plant on the slope, exhibited different growth rates and $\mathrm{N}$ utilization patterns. In the lower part of the slope, F. crenata grew faster, and its biomass distribution was more likely to be weighted to the aboveground sections; moreover, it utilized more $\mathrm{NO}_{3}^{-}$than the upper slope. Previous studies did not analyze the $\mathrm{N}$ dynamics on the basis of gross rates and microbial populations responsible for the $\mathrm{N}$ dynamics on the forest slope. However, we hypothesized that the population dynamics of ammonifiers and nitrifiers in the soil environment along the slope affects the production and consumption of $\mathrm{NH}_{4}^{+}$ and $\mathrm{NO}_{3}^{-}$which can influence plant distribution or growth rate and the $\mathrm{N}$ utilization pattern of $F$. crenata.

In the present study, we investigated how the microbial population dynamics reflected the bioavailable $\mathrm{N}$ dynamics with the physicochemical gradient along a slope in the Ashiu forest. We specifically analyzed how the soil environmental gradient affected the $\mathrm{NH}_{4}^{+}$and $\mathrm{NO}_{3}^{-}$production rates by altering populations of ammonifiers and nitrifiers. We also addressed how these relationships affected $\mathrm{N}$ uptake and growth of plants. We hypothesized that we could consider almost all bacteria to be ammonifiers because $\mathrm{NH}_{4}^{+}$production can occur via the assimilation of small organic $\mathrm{N}$ compounds such as amino acids, amino sugars, and nucleotides which all bacteria can be involved in (Schimel and Bennett, 2004; Myrold and Bottomley, 2008; Bottomley et al., 2012; Isobe and Ohte, 2014). We also analyzed ammonia-oxidizing bacteria and archaea as nitrifiers, which are responsible for the rate-limiting step of nitrification, ammonia oxidation (Isobe et al., 2011a).

\section{MATERIALS AND METHODS STUDY SITE}

The study was conducted in a cool-temperate broadleaved deciduous forest in the Kyoto University Ashiu Forest Research Station, Kyoto Prefecture, Japan $\left(35^{\circ} 18^{\prime} \mathrm{N}, 135^{\circ} 43^{\prime} \mathrm{E}\right)$. The forest is located in a mountainous area at elevations of $680-720$ masl. In this area, forests are dominated by broadleaved deciduous tree species, including F. crenata Blume and Quercus crispula Blume, and they have remained intact since 1898 or earlier. The mean annual temperature and precipitation over a 56-year period at a weather station (640 masl) located approximately $1 \mathrm{~km}$ from the study site were approximately $10^{\circ} \mathrm{C}$ and $2495 \mathrm{~mm}$, respectively. More detailed information about the site was reported by Tateno and Takeda (2003).

\section{SOIL SAMPLING}

Soil sampling was conducted in June 2013. A 30-200-m transect (0.6 ha) from the valley bottom to the ridge top on a northwestfacing slope was established in a previous study. We sampled approximately $500 \mathrm{~g}$ of soil from the surface $0-10 \mathrm{~cm}$ in the mineral layer at 11 points every $20 \mathrm{~m}$ from the top to the bottom along the center line of the transect. The soil was sieved through a $2-\mathrm{mm}$ mesh.

\section{SOIL CHEMISTRY ANALYSIS}

The soil water content was measured by drying $20 \mathrm{~g}$ of soil at $105^{\circ} \mathrm{C}$ for $24 \mathrm{~h}$ in a ventilated oven. The soil $\mathrm{pH}$ was measured using a pH meter (Horiba, Kyoto, Japan) after extracting $5 \mathrm{~g}$ of soil in $25 \mathrm{~mL}$ of water. The $\mathrm{NH}_{4}^{+}$and $\mathrm{NO}_{3}^{-}$concentrations in soil samples were determined using the indophenol and denitrifier methods (Isobe et al., 2011b), respectively, after extracting $7 \mathrm{~g}$ of soil with $35 \mathrm{~mL}$ of $2-\mathrm{M} \mathrm{KCl}$ solution. The concentration of dissolved organic nitrogen (DON) in the soil extracted with $\mathrm{KCl}$ solution was determined using a TOC/TN analyzer (TOC-V; Shimadzu, Kyoto, Japan).

\section{MEASUREMENT OF THE GROSS AND NET RATES OF $\mathrm{NH}_{4}^{+}$ PRODUCTION AND NITRIFICATION}

The gross rates of $\mathrm{NH}_{4}^{+}$production and nitrification in soils were determined using the isotope dilution method (Hart et al., 1994). Two subsamples ( $7 \mathrm{~g}$ each, equivalent to about $3.5 \mathrm{~g}$ of dry soil) from each soil sample were used for the analysis of $\mathrm{NH}_{4}{ }^{+}$ production or nitrification during 24 -h incubation. The detailed procedures have been reported previously (Isobe et al., 2011b,c; Urakawa et al., 2014). The concentrations and $\mathrm{N}$ isotope ratios of $\mathrm{NH}_{4}^{+}$or $\mathrm{NO}_{3}^{-}$in the $2 \mathrm{M} \mathrm{KCl}$ extracts were determined according to the method of Isobe et al. (2011b). The gross soil $\mathrm{NH}_{4}^{+}$production and nitrification rates were calculated according to the equations of Kirkham and Bartholomew (1954) using the concentrations and $\mathrm{N}$ isotope ratios for $\mathrm{NH}_{4}^{+}$and $\mathrm{NO}_{3}^{-}$, respectively. The gross $\mathrm{NH}_{4}^{+}$and $\mathrm{NO}_{3}^{-}$consumption rates were calculated in the same manner. The gross $\mathrm{NH}_{4}^{+}$immobilization rate was calculated by substituting the gross nitrification rate with the gross $\mathrm{NH}_{4}^{+}$consumption rate. The gross $\mathrm{NO}_{3}^{-}$immobilization rate was considered to be the same as the $\mathrm{NO}_{3}^{-}$consumption rate because denitrification can be minimized during aerobic incubation. Immobilization includes microbial assimilation and any 
other consumption process, but we assumed that the immobilization process during the 24 - $h$ incubation was the microbial assimilation process because abiotic consumption processes are more likely to occur in a short period after the ${ }^{15} \mathrm{~N}$ addition (i.e., $<2 \mathrm{~h}$ ). The percentage of nitrification was calculated by gross $\mathrm{NH}_{4}^{+}$production rate divided by gross nitrification rate which presented the proportion of the produced $\mathrm{NH}_{4}^{+}$that is being converted to $\mathrm{NO}_{3}^{-}$via nitrification. The net rates of $\mathrm{NH}_{4}^{+}$production and nitrification were calculated as the concentration changes in $\mathrm{NH}_{4}^{+}$and $\mathrm{NO}_{3}^{-}$, respectively, during the 24-h incubation.

\section{QUANTIFICATION OF THE BACTERIAL 16S rRNA GENE AND BACTERIAL AND ARCHAEAL AmoA GENES}

The bacterial 16S rRNA gene and bacterial and archaeal AmoA genes $(a m o A)$ were quantified to estimate the sizes of the populations of ammonifiers and nitrifiers. The bacterial 16S rRNA gene was determined by qPCR using the primers, 357f-520r, and the StepOne real-time PCR system (Applied Biosystems, Tokyo, Japan). The bacterial and archaeal amoA genes were also determined by qPCR using the primers amoAlf and amoA2r and primers CrenamoA23f and CrenamoA616r (Nicol et al., 2008), respectively. Each reaction mixture $(20 \mu \mathrm{L})$ contained the KOD SYBR green PCR master mixture (Toyobo, Tokyo, Japan), $0.2 \mu \mathrm{M}$ of each primer, $0.5 \mu \mathrm{g} \mathrm{mL}-1$ of bovine serum albumin, and $10 \mathrm{ng}$ of DNA template. To generate standard curves $\left(10^{1}-10^{7}\right.$ copies per reaction mixture), we used the bacterial 16S rRNA gene fragment of Pseudomonas stuzeri, the bacterial amoA fragment of Nitrosospira multiformis ATCC 25196, and the archaeal $a m o A$ fragment of the soil clone obtained in a previous study (Isobe et al., 2012). The reactions were performed in the following conditions: initial annealing at $98^{\circ} \mathrm{C}$ for $2 \mathrm{~min}$, followed by 45 cycles at $98^{\circ} \mathrm{C}$ for $10 \mathrm{~s}, 58^{\circ} \mathrm{C}$ for $30 \mathrm{~s}$ for the bacterial $16 \mathrm{~S}$ rRNA gene or $55^{\circ} \mathrm{C}$ for $30 \mathrm{~s}$ for bacterial/archaeal $a m o A$, and $72^{\circ} \mathrm{C}$ for $30 \mathrm{~s}$. The amplification efficiency of all the genes during standard curve generation was $>90 \%$ and the standard curves had high correlation coefficients $\left(R^{2}>0.95\right)$. The amplification of DNA fragments of the correct size was confirmed by dissociation curve analysis and agarose gel electrophoresis.

\section{DATA ANALYSIS}

To highlight the differences in the soil properties, $\mathrm{N}$ dynamics, and gene abundances between the upper and lower parts of the slope, we divided the data obtained into two categories [data derived from soils sampled at points $0-120 \mathrm{~m}$ from the top as the upper part $(N=5)$, and from 120 to $200 \mathrm{~m}$ as the lower part $(N=6)$ ], which we compared using an unequal variance $t$-test. Plant distribution was clearly different between upper and lower parts of the slope (Tateno and Takeda, 2003). The relationship between the two variables in all samples was assessed by correlation analysis to identify possible factors that affected the gross rate of $\mathrm{N}$ transformation and gene abundances $(N=11)$. An $\alpha<0.05$ was considered statistically significant for both tests. Path analysis was also used to determine the factors that affected the gross rates and abundances. In the path analysis, an experimentally supported theory was used to formulate a simple model of the causal and noncausal relationships between the variables (Figure 1A). Specifically, the gross $\mathrm{N}$ transformation rate can be affected by the

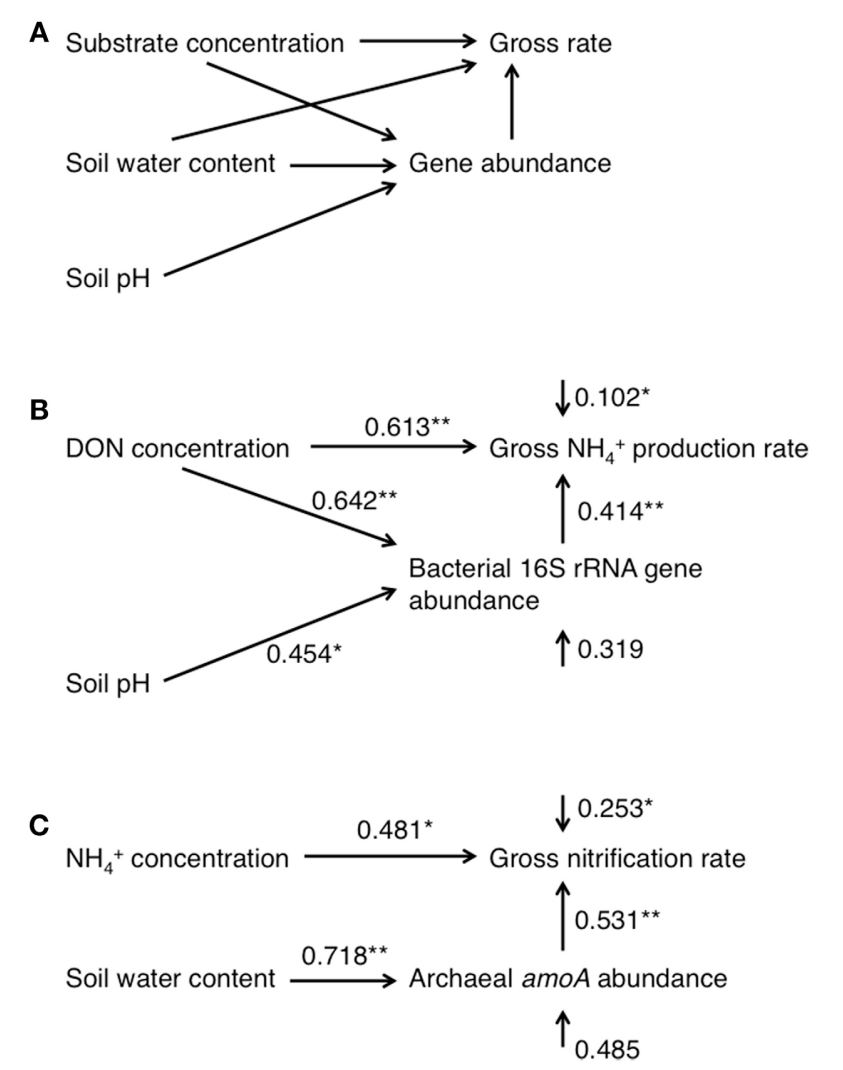

FIGURE 1 | Path diagrams representing the full model $(A)$ and the final models used to describe the patterns observed in the gross $\mathrm{NH}_{4}^{+}$ production rate (B) and gross nitrification rate (C). The numbers associated with the arrows between two variables are the partial regression coefficients derived from multiple regressions. The numbers associated with the arrows of single variables represent the unexplained variation (1- $\left.R^{2}\right)$, which represent the effects of unmeasured variables and measurement error. All pathways are significant in the final model $(* p<0.05 ; * * p<0.01)$.

$\mathrm{N}$-substrate supply, the population size of microorganisms that utilize the substrate for its transformation, and the water content. The population size is also affected by the N-substrate supply, soil $\mathrm{pH}$, and soil water content. The substrate and microorganisms should be the minimum requirements for $\mathrm{N}$ transformation. Water mediates all physiological reactions and microbial growth, and $\mathrm{pH}$ also has a great impact on growth. In the analysis of the gross $\mathrm{NH}_{4}^{+}$production rate, we used the DON concentration as the substrate supply and the abundance of the bacterial $16 \mathrm{~S}$ rRNA gene as the population size. In the analysis of the gross nitrification rate, we used the $\mathrm{NH}_{4}^{+}$concentration and the gross $\mathrm{NH}_{4}^{+}$production rate as the substrate supply, and the abundance of the bacterial and archaeal $a m o A$ as the population size. Reduced models were created by eliminating the paths with the highest probability values in a stepwise manner until all paths between two variables were significant $(p<0.05)$. Because of the small number of samples and variables, we performed these processes manually and only one reduced model maintained all paths between two variables with significance (Figures 1B,C). To 
account for differences in the magnitudes of data, the measurement scales were changed by standardizing all data to a similar numeric magnitude before calculating the variance-covariance matrices. All statistical analyses were performed using the R software (version 3.1.1, R Development Core Team, 2007) and path analysis was performed using the structural equation modeling function in the sem package in $\mathrm{R}$.

\section{RESULTS}

Table 1 shows the soil properties (water content, $\mathrm{pH}$, and DON/NH $\mathrm{NH}_{4}^{+} / \mathrm{NO}_{3}^{-}$concentrations), $\mathrm{N}$ transformation rates (gross rates of $\mathrm{NH}_{4}^{+}$production/consumption/immobilization, nitrification, and $\mathrm{NO}_{3}^{-}$immobilization, and net rates of $\mathrm{NH}_{4}^{+}$production and nitrification), and gene abundances (abundances of the bacterial 16S rRNA gene and archaeal $a m o A$ ) in the upper and lower parts of the slope. Bacterial amoA was detected only in the sampling points at the lowest positions $\left(7.1 \times 10^{6}\right.$ copy/g-dry soil). With respect to the soil properties, the water content, soil $\mathrm{pH}$, and $\mathrm{NH}_{4}^{+}$concentration did not differ significantly between the upper and lower parts, whereas the DON and $\mathrm{NO}_{3}^{-}$concentrations were higher in the lower part. The net $\mathrm{NH}_{4}^{+}$production rate was higher in the upper part, whereas the net nitrification rate was higher in the lower part. The gross rates of $\mathrm{N}$ transformation were higher in the lower part, except for $\mathrm{NH}_{4}^{+}$and $\mathrm{NO}_{3}^{-}$ immobilization. The percentage of nitrification was also higher in the lower part. The abundances of the bacterial 16S rRNA gene and archaeal amoA were higher in the lower part.

To estimate the factors that affected the gross rates of $\mathrm{NH}_{4}^{+}$ production and nitrification, we performed correlation analyses of the gross rates and soil physicochemical properties or gene abundances and the results are shown in Table 2 . In particular, the gross rate of $\mathrm{NH}_{4}^{+}$production correlated with the abundance of the bacterial 16S rRNA gene (Figure 2). The gross rate of nitrification correlated with the abundance of archaeal amoA (Figure 2).
The correlation analysis (Table 2 ) showed that the soil water content, DON concentration, and the abundance of the bacterial $16 \mathrm{~S}$ rRNA gene were possible factors that affected the gross $\mathrm{NH}_{4}^{+}$ production rate, whereas the gross $\mathrm{NH}_{4}^{+}$production rate, $\mathrm{NH}_{4}^{+}$ concentration, and the abundance of archaeal amoA were possible factors that affected the gross nitrification rate. These variables do not always have direct effects on the gross rates of $\mathrm{NH}_{4}^{+}$production or nitrification; thus, we performed path analysis based on the assumptions, described in Figure 1A, to consider the indirect influences on the gross rates. The results of the analysis (Figures 1B,C) suggest that the gross $\mathrm{NH}_{4}^{+}$production rate was affected by both the DON concentration and the abundance of the bacterial 16S rRNA gene, whereas the abundance of the bacterial 16S rRNA gene was affected by both the DON concentration and soil $\mathrm{pH}$. The gross nitrification rate was affected by both the $\mathrm{NH}_{4}^{+}$concentration and the abundance of archaeal amoA, whereas the abundance of archaeal $a m o A$ was affected by the soil water content. We did not use the gross $\mathrm{NH}_{4}^{+}$production rate as the resource parameter (Figure 1A) instead of or in addition to the $\mathrm{NH}_{4}^{+}$concentration in the analysis of the gross nitrification rate, because there was high multicollinearity between the gross $\mathrm{NH}_{4}^{+}$production rate and the abundance of archaeal amoA, which interfered with the statistical evaluation of the influence of the gross $\mathrm{NH}_{4}^{+}$production rate.

\section{DISCUSSION \\ SOIL CHEMISTRY AND N DYNAMICS ON THE SLOPE}

The soil water content and $\mathrm{pH}$ did not differ significantly between the upper and lower parts of the slope because of the large standard error, but they increased gradually down the slope from the top to the bottom (see "vs. sampling position" in Table 2), which was consistent with the results of a previous study conducted in 1997, as reported previously (Tateno and Takeda, 2003). The net rates of $\mathrm{NH}_{4}^{+}$production and nitrification suggest that

Table 1 | Soil properties, $\mathbf{N}$ transformation rates, and gene abundances in upper and lower parts on the forest slope.

\begin{tabular}{|c|c|c|c|c|}
\hline & & Upper part & Lower part & $p$-Value \\
\hline Water content & $(\%)$ & $33.8(2.56)$ & $41.4(4.16)$ & 0.08 \\
\hline Soil pH & & $4.1(0.12)$ & $4.5(0.21)$ & 0.06 \\
\hline Soil $\mathrm{NH}_{4}^{+}$concentration & (mg-N/kg-dry soil) & $8.9(2.1)$ & $13.2(1.8)$ & 0.08 \\
\hline Soil $\mathrm{NO}_{3}^{-}$concentration & (mg-N/kg-dry soil) & $13.2(1.8)$ & $21.5(5.3)$ & 0.05 \\
\hline Gross $\mathrm{NH}_{4}^{+}$production rate & (mg-N/kg-dry soil/day) & $2.71(0.46)$ & $12.36(3.09)$ & $<0.01$ \\
\hline Gross $\mathrm{NH}_{4}^{+}$consumption rate & (mg-N/kg-dry soil/day) & $0.36(1.22)$ & $12.23(2.78)$ & $<0.01$ \\
\hline Gross $\mathrm{NH}_{4}^{+}$immobilization rate & (mg-N/kg-dry soil/day) & $0.42(1.46)$ & $5.38(2.39)$ & 0.06 \\
\hline Gross nitrification rate & (mg-N/kg-dry soil/day) & $0.48(0.16)$ & $6.85(1.15)$ & $<0.01$ \\
\hline Gross $\mathrm{NO}_{3}^{-}$immobilization rate & (mg-N/kg-dry soil/day) & $0.6(0.42)$ & $0.53(0.63)$ & 0.46 \\
\hline
\end{tabular}

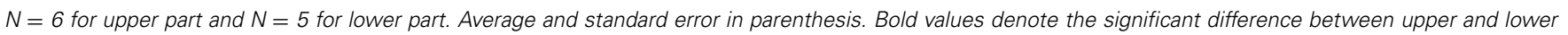
parts $(p<0.05)$. 
Table 2 | Correlation with gross rates of $\mathrm{NH}_{4}^{+}$production and nitrification, abundance of bacterial 16S rRNA gene and archaeal amoA, or sampling position.

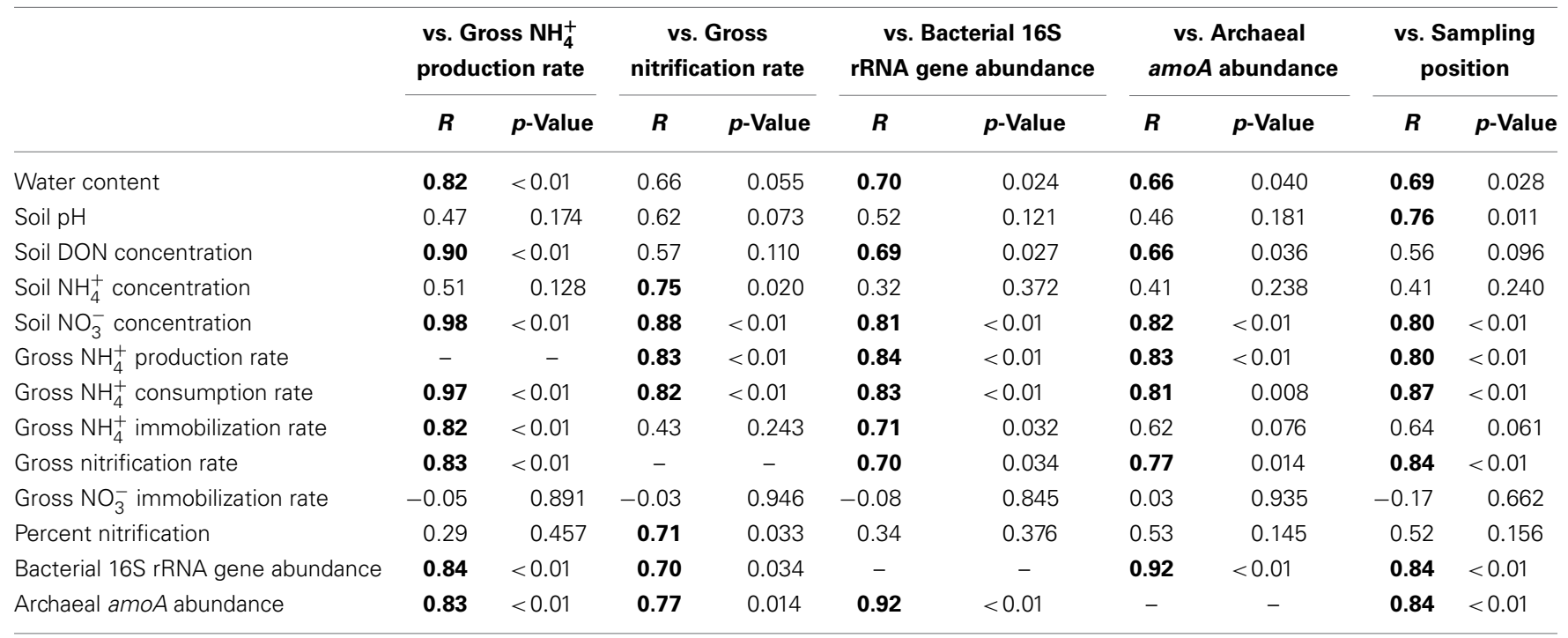

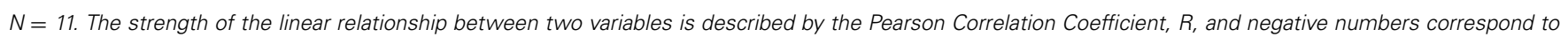

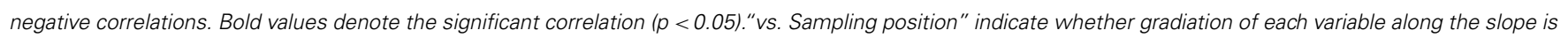
significant or not.

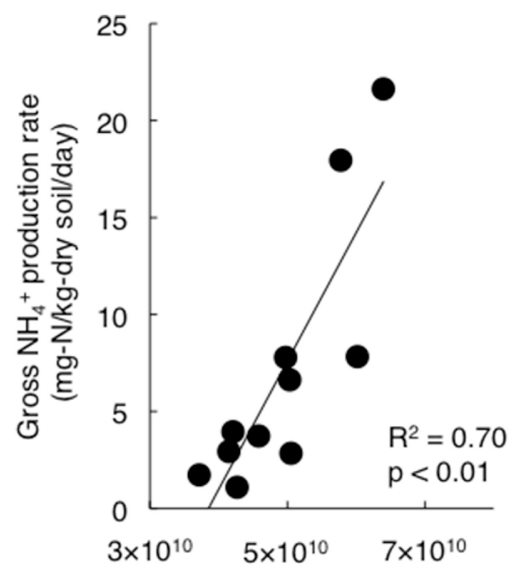

Abundance of bacterial 16S rRNA gene (copy/g-dry soil)

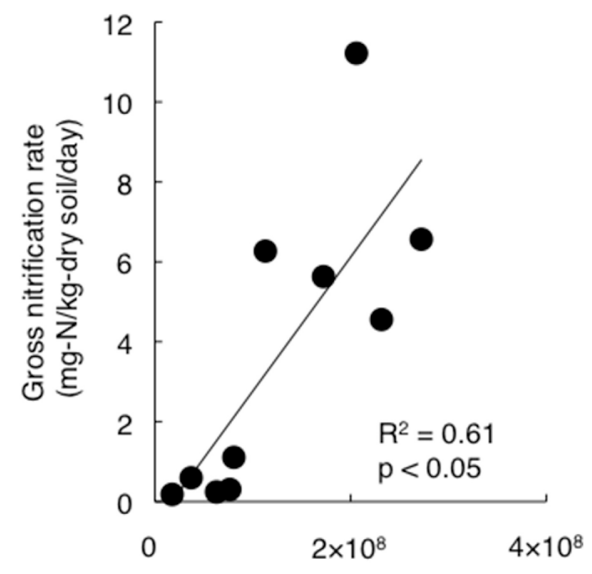

Abundance of archaeal amoA (copy/g-dry soil)

FIGURE 2 | Relationships between the gross $\mathrm{NH}_{4}^{+}$production rate and the bacterial $16 \mathrm{~S}$ rRNA gene abundance (Left panel, $y=7 \times 10^{-10} x-25.5$, $\left.R^{2}=0.70, p<0.05\right)$, and between the gross nitrification rate and the archaeal amoA abundance $\left(\right.$ Right panel, $\left.y=3 \times 10^{-8} x-0.5, R^{2}=0.61, p<0.05\right)$.

$\mathrm{NH}_{4}^{+}$tended to accumulate in the upper part of the slope whereas $\mathrm{NO}_{3}^{-}$tended to accumulate in the lower part (Table 1). This indicates that the available $\mathrm{N}$ for plants in the surface $0-10 \mathrm{~cm}$ mineral soil was likely to be $\mathrm{NH}_{4}^{+}$in the upper part and $\mathrm{NO}_{3}^{-}$ in the lower part. $\mathrm{NH}_{4}^{+}$accumulation was not observed in the lower part, but the gross $\mathrm{NH}_{4}^{+}$production rates in the lower part were much larger (Table 1), thereby suggesting that the concurrent production and consumption of larger amounts of $\mathrm{NH}_{4}^{+}$ occurred in the lower part. Nitrification and $\mathrm{NH}_{4}^{+}$immobilization were the dominant pathways of $\mathrm{NH}_{4}^{+}$consumption, with similar rates (Table $\mathbf{1}$ ). The higher gross nitrification rates in the lower part showed that larger amounts of $\mathrm{NO}_{3}^{-}$were produced, and the higher percentage of nitrification in the lower part suggests that more of the $\mathrm{NH}_{4}^{+}$produced via DON degradation was oxidized to $\mathrm{NO}_{3}^{-}$via nitrification. In addition, the gross rates of $\mathrm{NH}_{4}^{+}$immobilization and nitrification were much higher than the gross $\mathrm{NO}_{3}^{-}$immobilization rate in the lower part. This suggested that soil microorganisms were likely to utilize $\mathrm{NH}_{4}^{+}$rather than $\mathrm{NO}_{3}^{-}$for $\mathrm{N}$ assimilation, and a large amount of the $\mathrm{NO}_{3}^{-}$ produced via nitrification was not utilized. These results suggest that the $\mathrm{N}$ dynamics related to $\mathrm{NH}_{4}^{+}$and $\mathrm{NO}_{3}^{-}$were more prominent in the lower part because of the greater microbial $\mathrm{NH}_{4}^{+}$ 
production and consumption activities and the $\mathrm{N}$ availability, particularly the $\mathrm{NO}_{3}^{-}$availability, for plants was greater in the lower part because of the higher microbial nitrification activity but lower $\mathrm{NO}_{3}^{-}$immobilization activity.

\section{MICROBIAL POPULATION RESPONSIBLE FOR N TRANSFORMATION}

Similar to the gross rates of $\mathrm{NH}_{4}^{+}$production and nitrification, the populations of total bacteria and $\mathrm{NH}_{4}^{+}$-oxidizing archaea were higher in the lower part (Table 1). We hypothesized that almost all bacteria were involved in $\mathrm{NH}_{4}^{+}$production, and the positive correlation between the gross $\mathrm{NH}_{4}^{+}$production rates and abundances of the bacterial 16S rRNA gene supported our hypothesis. In general, $\mathrm{N}$ mineralization via DON degradation is measured in the form of $\mathrm{NH}_{4}^{+}$production as a single process, but it is actually the sum of multiple distinct physiological processes (Isobe and Ohte, 2014). Therefore, it is difficult to identify the microorganisms responsible for $\mathrm{NH}_{4}^{+}$production solely based on genetic information such as $a m o A$ for ammonia oxidizers or nirK/S for denitrifiers (Hawkes et al., 2005; Philippot et al., 2009; Isobe et al., 2012). Alternatively, $\mathrm{NH}_{4}^{+}$can potentially be produced via the direct enzymatic cleavage of a free amino group, amine$\mathrm{N}$, or amide- $\mathrm{N}\left(\mathrm{R}-\mathrm{NH}_{2}\right)$ inside cells that take up $\mathrm{R}-\mathrm{NH}_{2}$, and deaminase and deamidase enzymes can be produced by most bacteria (Schimel and Bennett, 2004; Myrold and Bottomley, 2008; Bottomley et al., 2012; Isobe and Ohte, 2014); thus, we hypothesized that almost all bacteria are involved in $\mathrm{NH}_{4}^{+}$production. There are few studies on microbial ecology associating with $\mathrm{NH}_{4}^{+}$ production; however, our study presents an alternative method for analyzing the mechanisms that regulate $\mathrm{NH}_{4}^{+}$production rate in soils. The positive correlation between the gross nitrification rates and the abundance of archaeal amoA (Figure 1) suggests that $\mathrm{NH}_{3}$-oxidizing archaea were mainly responsible for $\mathrm{NH}_{3}$ oxidation. Because $\mathrm{NH}_{3}$-oxidizing bacteria were detected only at the lowest point, their contribution to $\mathrm{NH}_{3}$ oxidation on the slope could be limited or site-specific. Previous studies have shown that gross or net nitrification rates correlate with the abundance of bacterial amoA in grassland or agricultural fields (Hawkes et al., 2005; Di et al., 2009; Jia and Conrad, 2009), but with the abundance of archaeal amoA in forests (Isobe et al., 2012). This supports the results of the present study, thereby suggesting that $\mathrm{NH}_{3}$-oxidizing archaea are likely to predominate in forests.

\section{REGULATION OF N DYNAMICS ON THE SLOPE}

The results of the path analysis of the regulation of the gross rates of $\mathrm{NH}_{4}^{+}$production and nitrification appeared to be reasonable because a substrate supply and microorganisms that utilize the substrate for transformation are the primary requirements for $\mathrm{N}$ transformation. The soil $\mathrm{pH}$ was suggested to be a major factor that affected the total bacterial population size. Previous study has also shown that the bacterial population size can be strongly affected by the soil pH (Rousk et al., 2010). The soil water content was suggested to be a strong factor that affected the population size of $\mathrm{NH}_{4}^{+}$-oxidizing archaea. Recently, Bustamante et al. (2012) also showed that the population size of $\mathrm{NH}_{4}^{+}$-oxidizing archaea responded positively to water availability. The gross $\mathrm{NH}_{4}^{+}$ production rate was indicated to be a factor that affected the gross nitrification rate, although we did not use it in the analysis.
A positive correlation between the gross rates of $\mathrm{NH}_{4}^{+}$production and nitrification is observed in many forests (Booth et al., 2005; Kuroiwa et al., 2011). Petersen et al. (2012) demonstrated the mutual correlations among the gross $\mathrm{NH}_{4}^{+}$production rate, abundance of bacterial amo $A$, and the net nitrification rate in various ecosystems in Alaska. Therefore, multicollinearity between the gross $\mathrm{NH}_{4}^{+}$production rate and the abundance of amoA during the analysis of gross nitrification may be observed in many forests. However, the gross $\mathrm{NH}_{4}^{+}$production rate is not always a dominant factor that affects the gross nitrification rate. Hawkes et al. (2005) showed that the gross $\mathrm{NH}_{4}^{+}$production rate was not considered to be a factor that affected either the gross nitrification rate or the abundance of bacterial amoA in a grassland soil, despite a strong correlation between them. We also have found that the gross nitrification rates positively correlated with the abundance of archaeal amoA in subtropical forest soils with different gross $\mathrm{NH}_{4}^{+}$production rates (Isobe, 2011). In the present study, the lack of statistical evaluation of the effect of the gross $\mathrm{NH}_{4}^{+}$production rate on the gross nitrification rate and the abundance of archaeal amoA was attributable to the low number of samples examined. Microbial $\mathrm{NH}_{4}^{+}$immobilization was one of main $\mathrm{N}$ transformation processes on the slope. As demonstrated by the correlation between the gross $\mathrm{NH}_{4}^{+}$immobilization rate and the abundance of the bacterial 16S rRNA gene (Table 2), gross $\mathrm{NH}_{4}^{+}$immobilization rate could be affected strongly by the size of the bacterial population because $\mathrm{NH}_{4}^{+}$, but not $\mathrm{NO}_{3}^{-}$, was the main form of $\mathrm{N}$ assimilated by microorganisms in the lower part of the slope. The results of the present study suggest that the gradients of soil environmental properties such as the $\mathrm{pH}$ and water content along the forest slope affected $\mathrm{N}$ transformation rates by altering the sizes of the microbial populations responsible for the $\mathrm{N}$ transformations. Figure 3 shows a conceptual diagram of the possible regulation of $\mathrm{N}$ transformation on the slope.

\section{INTERACTIONS BETWEEN MICROORGANISMS AND PLANTS VIA THE REGULATION OF N DYNAMICS}

The $\mathrm{N}$ availability for plants was higher in the lower part of the slope. In particular, the larger population size of $\mathrm{NH}_{3}$-oxidizing archaea was related to the higher $\mathrm{NO}_{3}^{-}$availability for plants. In addition, the microbial communities preferred $\mathrm{NH}_{4}^{+}$for $\mathrm{N}$ assimilation and supplied free $\mathrm{NO}_{3}^{-}$via nitrification. These results indicate that partitioning the bioavailable $\mathrm{N}$ can occur between microbial communities and plants. This could facilitated the higher growth and more active utilization of $\mathrm{NO}_{3}^{-}$by F. crenata on the lower slope, as shown in a previous study (Tateno et al., 2005). The higher water availability in the lower part, which is one of the general characteristics of forest slopes, also led to increases in the population size of $\mathrm{NH}_{3}$-oxidizing archaea and acceleration of the diffusion of the $\mathrm{NO}_{3}^{-}$produced, which could relieved the plants from water- and N-limiting conditions. However, the lower part could presented severe conditions for plants that selectively uptake $\mathrm{NH}_{4}^{+}$for $\mathrm{N}$ assimilation. The increased concentration of DON of which supply originates from the degradation of the plant litter could facilitate increases in the population size of total bacteria as the ammonifiers and the $\mathrm{NH}_{4}^{+}$ production rate. 


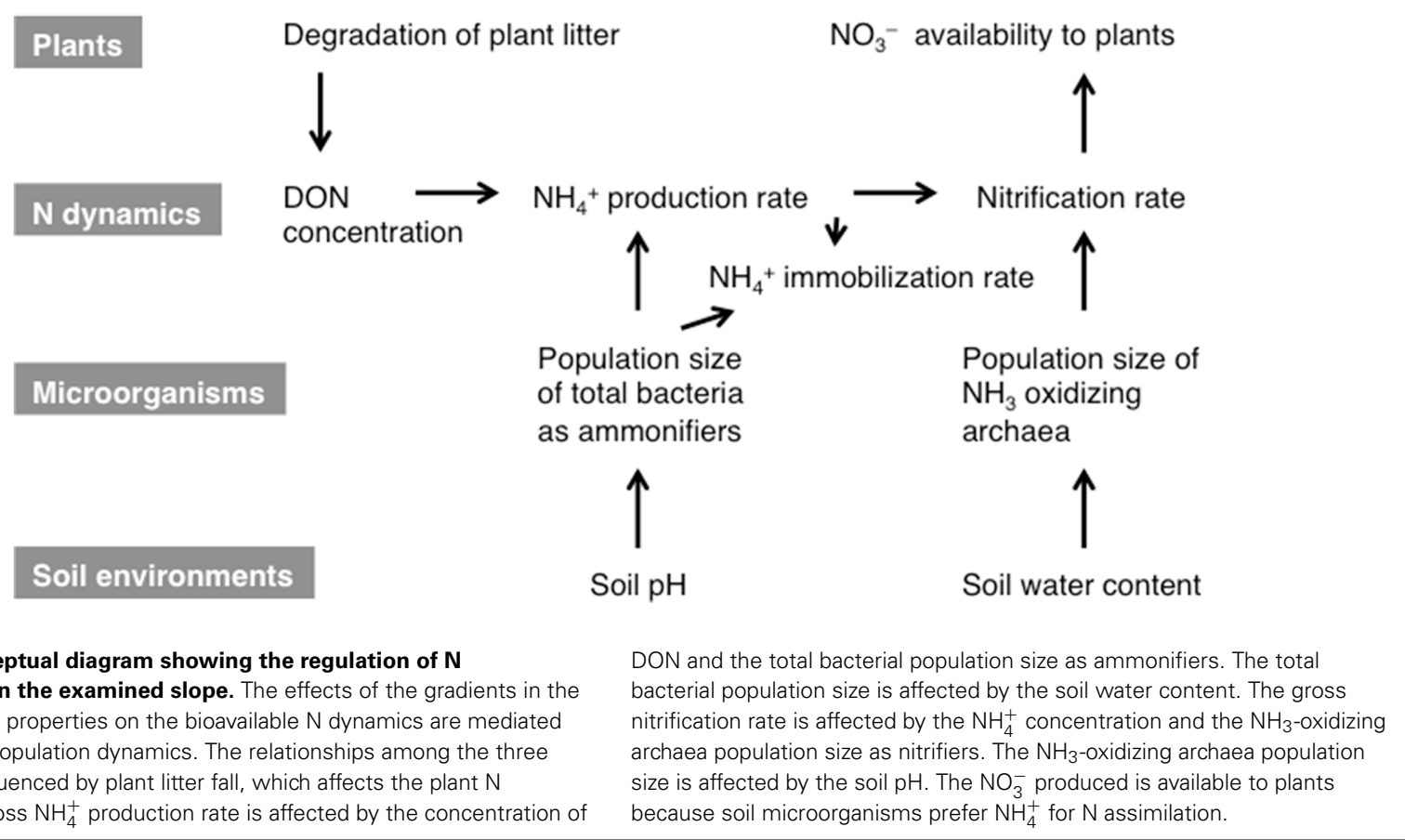

In summary, the results of this study suggest that the soil physicochemical gradient along the slope caused the spatial gradient of gross rates of $\mathrm{NH}_{4}^{+}$production and nitrification by altering the communities of ammonifiers and nitrifiers in the forest slope, which also affected plant growth via the supply of bioavailable $\mathrm{N}$ to plants. Many studies have investigated microorganism-plant interactions in forests by focusing on direct interactions such as ectomycorrhizal or endomycorrhizal symbiosis (Kohzu et al., 1999; Toljander et al., 2006; Hobbie and Hobbie, 2008). However, our study suggests that microorganism-plant interactions occur indirectly via microbial regulation of supply of the bioavailable $\mathrm{N}$. Let us be cautioned, however, that this study was performed in a single forest slope. Obtaining a definitive picture of the microbial regulation of bioavailable $\mathrm{N}$ dynamics in forest soils will require studies in forests with different vegetation types (e.g., planted forests) or different pattern of $\mathrm{N}$ dynamics, which should be the objective of future work.

\section{ACKNOWLEDGMENTS}

This work was supported by Grants-in-Aid for Scientific Research from the Japanese Society for the Promotion of Science (Nos. 25252026, 25550009, 26292085, and 26712015) and the GRENE/Ecoinformatics project from the Ministry of Education, Culture, Sports, Science and Technology, Japan.

\section{REFERENCES}

Band, L. E., Tague, C. L., Groffman, P., and Belt, K. (2001). Forest ecosystem processes at the watershed scale: hydrological and ecological controls of nitrogen export. Hydrol. Process. 15, 2013-2028. doi: 10.1002/hyp.253

Booth, M. S., Stark, J. M., and Rastetter, E. (2005). Controls on nitrogen cycling in terrestrial ecosystems: a synthetic analysis of literature data. Ecol. Monogr. 75, 139-157. doi: 10.1890/04-0988

Bottomley, P. J., Taylor, A. E., and Myrold, D. D. (2012). A consideration of the relative contributions of different microbial subpopulations to the soil $\mathrm{N}$ cycle. Front. Microbiol. 3:373. doi: 10.3389/fmicb.2012 00373

Bustamante, M., Verdejo, V., Zúñiga, C., Espinosa, F., Orlando, J., and Carú, M. (2012). Comparison of water availability effect on ammonia-oxidizing bacteria and archaea in microcosms of a Chilean semiarid soil. Front. Microbiol. 3:282. doi: $10.3389 /$ fmicb. 2012.00282

Di, H. J., Cameron, K. C., Shen, J. P., Winefield, C. S., O'Callaghan, M., Bowatte, S., et al. (2009). Nitrification driven by bacteria and not archaea in nitrogen-rich grassland soils. Nat. Geosci. 2, 621-624. doi: 10.1038/ngeo613

Engelbrecht, B. M. J., Comita, L. S., Condit, R., Kursar, T. A., Tyree, M. T., Turner, B. L., et al. (2007). Drought sensitivity shapes species distribution patterns in tropical forests. Nature 447, 80-82. doi: 10.1038/nature05747

Enoki, T. (2003). Microtopography and distribution of canopy trees in a subtropical evergreen broad-leaved forest in the northern part of Okinawa Island, Japan. Ecol. Res. 18, 103-113. doi: 10.1046/j.1440-1703.2003.00549.x

Hart, S. C., Stark, J. M., Davidson, E. A., and Firestone, M. K. (1994). "Nitrogen mineralization, immobilization, and nitrification," in Methods of Soil Analysis. Part 2, Biochemical and Microbiological Properties, eds R. Weaver, S. Angle, P. Bottomley, D. Bezdicek, S. Smith, A. Tabatabai, and A. Wollum (Madison: Soil Science Society of America), 985-1018.

Hawkes, C. V., Wren, I. F., Herman, D. J., and Firestone, M. K. (2005). Plant invasion alters nitrogen cycling by modifying the soil nitrifying community. Ecol. Lett. 8, 976-985. doi: 10.1111/j.1461-0248.2005.00802.x

Hill, A., and Kemp, W. (1999). Nitrogen chemistry of subsurface storm runoff on forested Canadian Shield hillslopes. Water Resour. Res. 35, 811-821. doi: 10.1029/1998WR900083

Hirobe, M., Koba, K., and Tokuchi, N. (2003). Dynamics of the internal soil nitrogen cycles under moder and mull forest floor types on a slope in a Cryptomeria japonica D. Don plantation. Ecol. Res. 18, 53-64. doi: 10.1046/j.1440-1703.2003.00532.x

Hirobe, M., Tokuchi, N., and Iwatsubo, G. (1998). Spatial variability of soil nitrogen transformation patterns along a forest slope in a Cryptomeria japonica D. Don plantation. Eur. J. Soil Biol. 34, 123-131. doi: 10.1016/S1164-5563(00)88649-5

Hobbie, E. A., and Hobbie, J. E. (2008). Natural abundance of $15 \mathrm{~N}$ in nitrogenlimited forests and tundra can estimate nitrogen cycling through mycorrhizal fungi: a review. Ecosystems 11, 815-830. doi: 10.1007/s10021-008-9159-7

Hook, P., and Burke, I. (2000). Biogeochemistry in a shortgrass landscape: control by topography, soil texture, and microclimate. Ecology 81, 2686-2703. doi: 10.1890/0012-9658(2000)081[2686:BIASLC]2.0.CO;2 
Isobe, K. (2011). Nitrogen Flow and Nitrifying Microbial Communities in Subtropical Forest Soils Receiving High N Deposition in CHINA. Doctoral dissertation of The University of Tokyo, Tokyo.

Isobe, K., Koba, K., Otsuka, S., and Senoo, K. (2011a). Nitrification and nitrifying microbial communities in forest soils. J. For. Res. 16, 351-362. doi: 10.1007/s10310-011-0266-5

Isobe, K., Koba, K., Suwa, Y., Ikutani, J., Fang, Y., Yoh, M., et al. (2012). High abundance of ammonia-oxidizing archaea in acidified subtropical forest soils in southern China after long-term $\mathrm{N}$ deposition. FEMS Microbiol. Ecol. 80, 193-203. doi: 10.1111/j.1574-6941.2011.01294.x

Isobe, K., Koba, K., Ueda, S., Senoo, K., Harayama, S., and Suwa, Y. (2011c). A simple and rapid GC/MS method for the simultaneous determination of gaseous metabolites. J. Microbiol. Methods 84, 46-51. doi: 10.1016/j.mimet.2010.10.009

Isobe, K., and Ohte, N. (2014). Ecological perspectives on microbes involved in N-cycling. Microbes Environ. 29, 4-16. doi: 10.1264/jsme2.ME13159

Isobe, K., Suwa, Y., Ikutani, J., Kuroiwa, M., Makita, T., Takebayashi, Y., et al. (2011b). Analytical techniques for quantifying $15 \mathrm{~N} / 14 \mathrm{~N}$ of nitrate, nitrite, total dissolved nitrogen and ammonium in environmental samples using a gas chromatograph equipped with a quadrupole mass spectrometer. Microbes Environ. 26, 46-53. doi: 10.1264/jsme2.ME10159

Jia, Z., and Conrad, R. (2009). Bacteria rather than Archaea dominate microbial ammonia oxidation in an agricultural soil. Environ. Microbiol. 11, 1658-1671. doi: 10.1111/j.1462-2920.2009.01891.x

Kirkham, D., and Bartholomew, W. V. (1954). Equations for following nutrient transformations in soil, utilizing tracer data1. Soil Sci. Soc. Am. J. 18, 33. doi: 10.2136/sssaj1954.03615995001800010009x

Kohzu, A., Yoshioka, T., Ando, T., Takahashi, M., Koba, K., and Wada, E. (1999). Natural $13 \mathrm{C}$ and $15 \mathrm{~N}$ abundance of field-collected fungi and their ecological implications. New Phytol. 144, 323-330. doi: 10.1046/j.1469-8137.1999.00508.x

Koyama, L., Hirobe, M., Koba, K., and Tokuchi, N. (2013). Nitrate-use traits of understory plants as potential regulators of vegetation distribution on a slope in a Japanese cedar plantation. Plant Soil 362, 119-134. doi: 10.1007/s11104-01 2-1257-9

Kuroiwa, M., Koba, K., Isobe, K., Tateno, R., Nakanishi, A., Inagaki, Y., et al. (2011). Gross nitrification rates in four Japanese forest soils: heterotrophic versus autotrophic and the regulation factors for the nitrification. J. For. Res. 16, 363-373. doi: 10.1007/s10310-011-0287-0

Kuzyakov, Y., and $\mathrm{Xu}$, X. (2013). Competition between roots and microorganisms for nitrogen?: mechanisms and ecological relevance. New Phytol. 198, 656-669. doi: $10.1111 / \mathrm{nph} .12235$

Myrold, D. D., and Bottomley, P. J. (2008). "Nitrogen mineralization and immobilization," in Nitrogen in Agricultural Systems, eds J. S. Schepers and W. R. Raun (Madison, WI: ASA-CSSA-SSSA), 153-168.

Nicol, G. W., Leininger, S., Schleper, C., and Prosser, J. I. (2008). The influence of soil $\mathrm{pH}$ on the diversity, abundance and transcriptional activity of ammonia oxidizing archaea and bacteria. Environ. Microbiol. 10, 2966-2978. doi: 10.1111/j.1462-2920.2008.01701.x

Nishina, K., Takenaka, C., and Ishizuka, S. (2009a). Spatial variations in nitrous oxide and nitric oxide emission potential on a slope of Japanese cedar (Cryptomeria japonica) forest. Soil Sci. Plant Nutr. 55, 179-189. doi: 10.1111/j.1747-0765.2007.00315.x

Nishina, K., Takenaka, C., and Ishizuka, S. (2009b). Spatiotemporal variation in $\mathrm{N}_{2} \mathrm{O}$ flux within a slope in a Japanese cedar (Cryptomeria japonica) forest. Biogeochemistry 96, 163-175. doi: 10.1007/s10533-009-9356-2

Penna, D., Borga, M., Norbiato, D., and Dalla Fontana, G. (2009). Hillslope scale soil moisture variability in a steep alpine terrain. J. Hydrol. 364, 311-327. doi: 10.1016/j.jhydrol.2008.11.009

Petersen, D. G., Blazewicz, S. J., Firestone, M., Herman, D. J., Turetsky, M., and Waldrop, M. (2012). Abundance of microbial genes associated with nitrogen cycling as indices of biogeochemical process rates across a vegetation gradient in Alaska. Environ. Microbiol. 14, 993-1008. doi: 10.1111/j.14622920.2011.02679.x

Philippot, L., Cuhel, J., Saby, N. P. A., Chèneby, D., Chronáková, A., Bru, D., et al. (2009). Mapping field-scale spatial patterns of size and activity of the denitrifier community. Environ. Microbiol. 11, 1518-1526. doi: 10.1111/j.14622920.2009.01879.x

Rousk, J., Bååth, E., Brookes, P. C., Lauber, C. L., Lozupone, C., Caporaso, J. G., et al. (2010). Soil bacterial and fungal communities across a $\mathrm{pH}$ gradient in an arable soil. ISME J. 4, 1340-1351. doi: 10.1038/ismej.2010.58

Schimel, J. P., and Bennett, J. (2004). Nitrogen mineralization: challenges of a changing paradigm. Ecology 85, 591-602. doi: 10.1890/03-8002

Tateno, R., Hishi, T., and Takeda, H. (2004). Above- and belowground biomass and net primary production in a cool-temperate deciduous forest in relation to topographical changes in soil nitrogen. For. Ecol. Manag. 193, 297-306. doi: 10.1016/j.foreco.2003.11.011

Tateno, R., Osada, N., Terai, M., Tokuchi, N., and Takeda, H. (2005). Inorganic nitrogen source utilization byFagus crenata on different soil types. Trees 19, 477-481. doi: 10.1007/s00468-005-0409-4

Tateno, R., and Takeda, H. (2003). Forest structure and tree species distribution in relation to topography-mediated heterogeneity of soil nitrogen and light at the forest floor. Ecol. Res. 18, 559-571. doi: 10.1046/j.1440-1703.2003.00578.x

Tateno, R., and Takeda, H. (2010). Nitrogen uptake and nitrogen use efficiency above and below ground along a topographic gradient of soil nitrogen availability. Oecologia 163, 793-804. doi: 10.1007/s00442-009-1561-0

Tokuchi, N., Hirobe, M., and Koba, K. (2000). Topographical differences in soil N transformation using $15 \mathrm{~N}$ dilution method along a slope in a conifer plantation forest in Japan. J. For. Res. 5, 13-19. doi: 10.1007/BF02762758

Toljander, J. F., Eberhardt, U., Toljander, Y. K., Paul, L. R., and Taylor, A. F. S. (2006). Species composition of an ectomycorrhizal fungal community along a local nutrient gradient in a boreal forest. New Phytol. 170, 873-883. doi: 10.1111/j.1469-8137.2006.01718.x

Tromp-van Meerveld, H. J., and McDonnell, J. J. (2006). On the interrelations between topography, soil depth, soil moisture, transpiration rates and species distribution at the hillslope scale. Adv. Water Resour. 29, 293-310. doi: 10.1016/j.advwatres.2005.02.016

Urakawa, R., Ohte, N., Shibata, H., Tateno, R., Hishi, T., Fukushima, K., et al. (2014). Biogeochemical nitrogen properties of forest soils in the Japanese archipelago. Ecol Res. doi: 10.1007/s11284-014-1212-8. (in press)

Vitousek, P., and Howarth, R. (1991). Nitrogen limitation on land and in the sea: how can it occur? Biogeochemistry 13, 87-115. doi: 10.1007/BF00002772

Conflict of Interest Statement: The authors declare that the research was conducted in the absence of any commercial or financial relationships that could be construed as a potential conflict of interest.

Received: 30 September 2014; accepted: 07 December 2014; published online: 07 January 2015.

Citation: Isobe K, Ohte N, Oda T, Murabayashi S, Wei W, Senoo K, Tokuchi N and Tateno $R$ (2015) Microbial regulation of nitrogen dynamics along the hillslope of a natural forest. Front. Environ. Sci. 2:63. doi: 10.3389/fenvs.2014.00063

This article was submitted to Soil Processes, a section of the journal Frontiers in Environmental Science.

Copyright $\odot 2015$ Isobe, Ohte, Oda, Murabayashi, Wei, Senoo, Tokuchi and Tateno. This is an open-access article distributed under the terms of the Creative Commons Attribution License (CC BY). The use, distribution or reproduction in other forums is permitted, provided the original author $(s)$ or licensor are credited and that the original publication in this journal is cited, in accordance with accepted academic practice. No use, distribution or reproduction is permitted which does not comply with these terms. 